\title{
Surface Area Estimation, Volume Change Detection in Lime Stone Quarry, Tirunelveli District Using Cartosat-1 Generated Digital Elevation Model (DEM)
}

\author{
Sudalaimuthu Karuppasamy1, Sudalayandi Kaliappan², R. Karthiga1, C. Divya1 \\ ${ }^{1}$ Department of Civil Engineering, Regional Campus, Anna University, Tirunelveli, India \\ ${ }^{2}$ Department of Civil Engineering, Anna University, Chennai, India \\ Email: karuppasamys@yahoo.com,drkalsun@gmail.com
}

Received 19 March 2016; accepted 14 May 2016; published 17 May 2016

Copyright (C) 2016 by authors and Scientific Research Publishing Inc.

This work is licensed under the Creative Commons Attribution International License (CC BY).

http://creativecommons.org/licenses/by/4.0/

(c) (i) Open Access

\begin{abstract}
The objective of the study was to estimate the change detection in a surface area and volume analysis of the lime stone quarry for the year 2006 and 2014 in Mannur, Tirunelveli district, Tamilnadu. Though the mining activities are essential for the cement factory, it depletes the ground water table and causes pollution to the Environment. The Integration of Remote Sensing and GIS are effective for analyzing the impact of quarrying on natural resources. In this study, Cartosat-1 satellite data generated Digital Elevation Model (DEM) for measuring surface area and the volume of Lime stone quarry. Temporal volume change study is essential for the government to restrain the misuse of the natural resources by the private sector. In 2006, the surface area and volume of lime stone excavated by 8 mining quarries was $1,991,759.68 \mathrm{~m}^{2}$ and $112,398,931.9 \mathrm{~m}^{3}$ respectively. Meanwhile, the surface area utilized and volume of limestone production by the quarry was increased to $2,881,384.64 \mathrm{~m}^{2}$ and $156,806,929.9 \mathrm{~m}^{3}$ respectively during the year 2014 . In these 8 years period, quarry surface area utilization increased by $30 \%$ and limestone production increased by $\mathbf{2 8 \%}$ was observed. This study is useful for the government to monitor the natural resources restrain to over use by the private sector.
\end{abstract}

\section{Keywords}

Cartosat-1, Lime Stone, Quarry Surface Area, Photogrammetry, LPS, DEM 


\section{Introduction}

Mining is an activity that involves excavating the earth surface for the purpose of exploring the mineral wealth. Mining operations is done in the place called as quarry or quarry site. Mining is the world's oldest and highly economic activity next to agriculture. From the Pre-historic days, mining activities are considered as the icon of the civilization which tempts man to increase his life standard by exploring wealth from the Mother of Nature and one such doing is mineral excavation from earth surface [1]. Mining activities still remains as the world's most intensive and primary industrial activity which has undertook all environmental impact. The impact of mining can be significant on the surrounding land, water and air bodies, in any operational area [2]. The conflict between mining activities and environmental protection has increased in recent years and it requires improving information on the dynamics of local and regional scale impacts [3]. Mining without proper planning and lack of modern technology have adverse impacts on the atmosphere. Dust emission is one of the major effects of the practice of lime stone extraction in the atmosphere [4].

Surface mining causes extensive damage to flora, fauna [5] and tile/brick clay mining has adverse effect on existing land use/cover practices [6]. However, long time mining production driven, leading to soil degradation, toxic vegetation, contamination, mine dump disposal, landscape defacement and ground water pollution [7]. Ground water pollution causes mainly due to rainwater in the opencast mine pits percolates and degrade the ground water quality by increasing the total hardness and calcium content [8].

This study states the level of knowledge regarding volume estimation and depth change analysis of quarry from the generation of DEM by using Cartosat-1. Volume of mineral excavated and change in depth of the quarry which went even below the water table level, can be determined. Increase in volume of mining leads to the deduction in the ground water level and that the mining process below the water level makes the ground water to be intercepted and pumped out or lost by evaporation process thereby lowering of the water table occurs. This could result in loss of head or dewatering of wells within a radius of few kilometers of the mine. The Dewatering operation can show evidence of decreased water supply, water quality and reduce the water level in local or some time in regional level [9].

This impact can be minimized or reduced by estimating volume and depth change analysis of quarry by using possible surveying techniques. In reality, monitoring and controlling these activities was found difficult because it is more expensive and time consuming in producing reliable and up-to-date map by using Terrestrial surveying [10]. To overcome this disadvantage of terrestrial surveying technique. In 1970s, analog aerial photographs have been used for mapping spatial changes in mined areas [11], but this technique requires approval from the Government of India. Surveying and Photogrammetry, acquire every day more important role in mining exploitation. Unmanned Aerial Vehicles (UAV) captured images are effective and economical than classical surveying and terrestrial laser scanning in mining activity [12]. Remote sensing and GIS have often been used as informative and visual analytical tools by decision makers to monitor and determine the change detection and to estimate the impact of mining in an instant and economical manner. The spatial-temporal images captured by the multi temporal satellites such as Landsat Series, ASTER, ERS-1 were used to examine the areal expansion of quarries and its related impacts [13].

To depict the ground subsidence due to over excavation of minerals, stereo viewing of high resolution satellites are required. In this study, Cartosat- 1 data is used, because of its stereo viewing capability and the generation of DEM is found fast and accurate. DEM helps in estimation of volume and depth change analysis of quarry which is highly desirable. The Cartosat-1 is placed in the polar sun synchronous orbit of $618 \mathrm{~km}$ from earth surface which covers a large extent of the land surface. The satellite is equipped with 2 high resolution panchromatic sensors. The two sensors are acquiring stereo pairs from the same orbit. These stereo images are obtained in fore/after directions in near real time from the two sensors. The product of Cartosat- 1 is more useful in cartographic mapping and various GIS applications [14].

Remote sensing and GIS offers technically an excellent method of identifying the depletion of groundwater level with respect to increased volume of the excavation in quarry site and unplanned mining activities [15]. The main objective of the current study is to identification of number of quarries and volume estimation of quarries in Tirunelveli district for the years 2006 and 2014 using Indian Remote Sensing satellites. Photogrammetry and GIS seems to be the most appropriate solution for quarry monitoring and excavation volumes calculation. The Tirunelveli district is rich in limestone which gives a great support to the economic welfare and opportunities to increase the number of quarry site. 


\section{Study Area and Data Description}

\subsection{Study Area}

Tirunelveli is also known as Nellai, is a city in the South of Tamilnadu. It is shown in Figure 1. The River Tamirabarani is the main source of drinking water for the District. The river bisects the twin cities Tirunelveli and Palayamkottai before meeting its major and affluent tributary Chittar. The Tirunelveli is situated between $08^{\circ}$ $8^{\prime} \mathrm{N}$ and $09^{\circ} 23^{\prime} \mathrm{N}$ latitude and $77^{\circ} 09^{\prime} \mathrm{E}$ and $77^{\circ} 54^{\prime} \mathrm{E}$ longitude and spreaded for an area of $5942 \mathrm{~km}^{2}$, the total catchments area is $4500 \mathrm{~km}^{2}$ with Population density to be 362 person per $\mathrm{km}^{2}$ and its average elevation in 47 meter above the Mean Sea Level. Annual Rainfall prevails up to $680 \mathrm{~mm}$ per annum. The climate is hot and humid and the average temperature during summer is range from $25^{\circ} \mathrm{C}-41^{\circ} \mathrm{C}$. Due to the high presence of lime stone resources, Tirunelveli is having cement industries and also other Industries in include agricultural trading, and Tourism.

\subsection{Data}

Data used in this study is Cartosat-1 stereo data. It is capable to generate three dimensional earth information. Cartosat data products have varieties of format in which orthokit format was used for the study area. Cartosat-1 data pertaining to Tirunelveli district was used for this study. It was acquired on October 2006 and June 2014, Path and Row of the scene, 550 and 354. Cartosat-1 is capable of providing along-track stereo imagery which was launched on May 5, 2005. Stereo capability of Cartosat-1 provides the 3D feature extraction of the quarry area to measure the volume and surface area. The spatial resolution of Cartosat- 1 is 2.5 meter. It is sufficient enough to study about quarry volume estimation.

\section{Methods}

A systematic framework of methodology was used to measure the surface area and volume as shown in Figure 2. The methodology can be grouped into three stages. The first stage incorporates the Cartosat-1 Triangulation processing and the second stage is 3D feature extraction for volume and surface area estimation. The final stage is analyzing the change detection of surface area and volume for the year 2006 and 2014.

\subsection{Triangulation}

Triangulation was performed for Cartosat-1 using the Leica Photogrammetry Suite software. It was done to relate the image coordinate system to ground coordinate system with the help of GCP that are collected from the field. Triangulation is the prerequisite for DEM generation and Feature collection. Triangulation consists of Interior and Exterior orientation.The interior orientation was computed for both before and after camera images

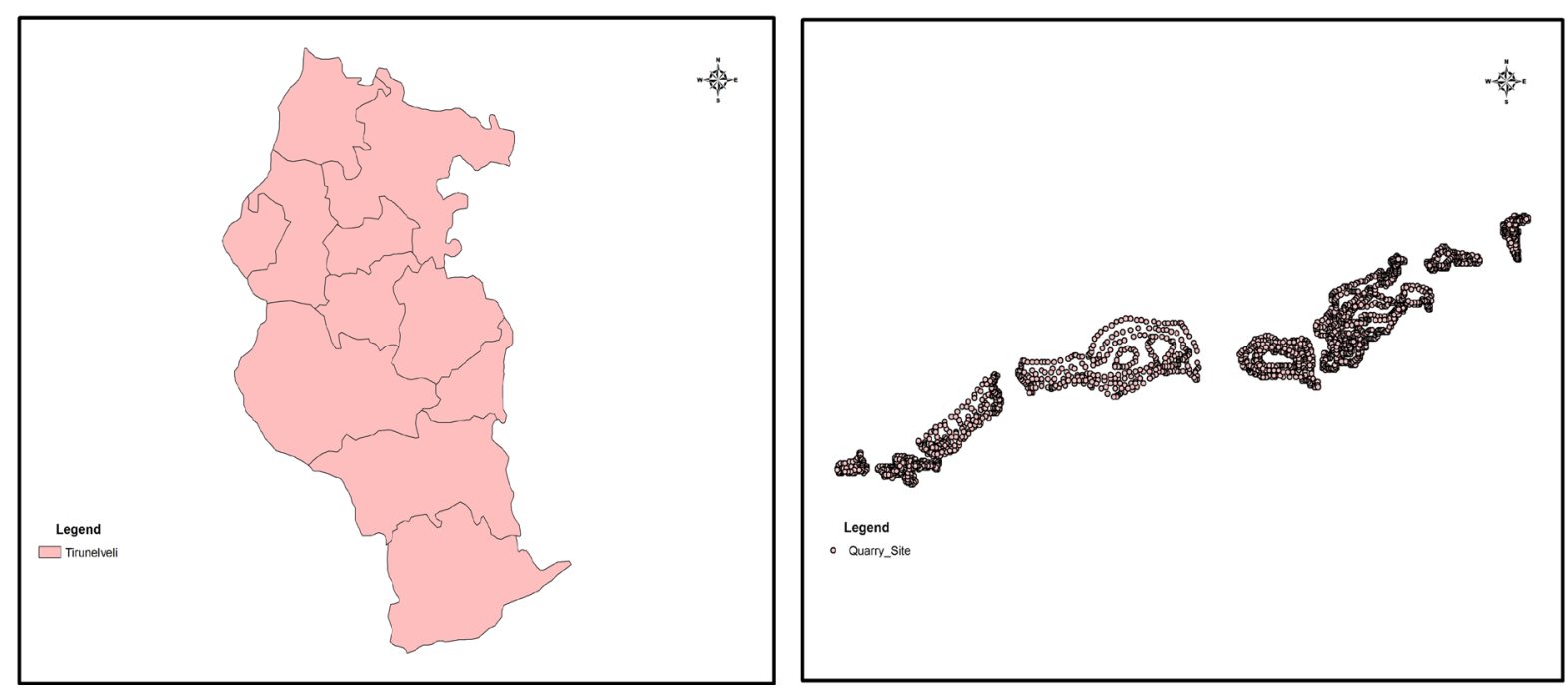

Figure 1. Study area. 


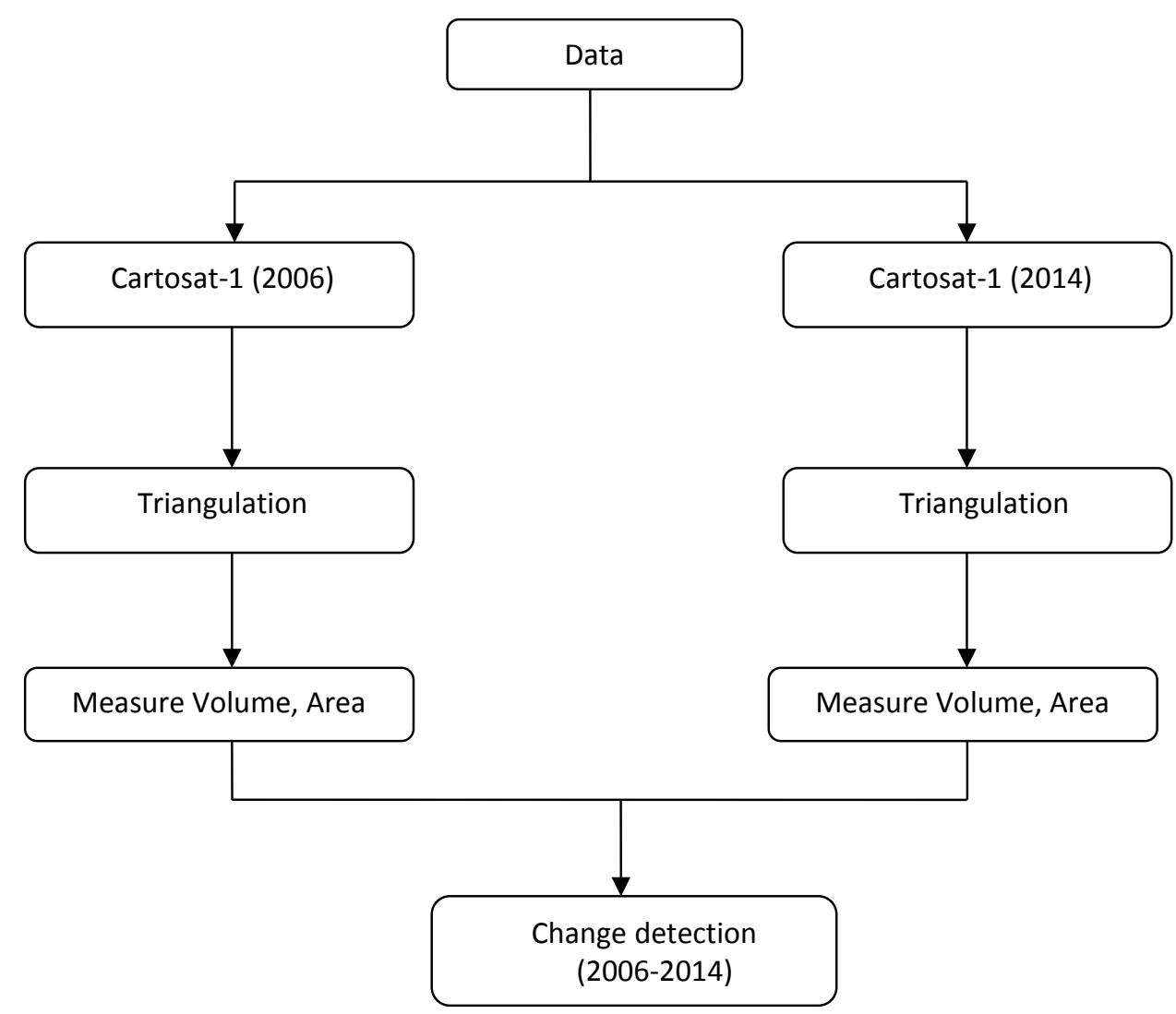

Figure 2. Methodology adopted for measuring volume and surface area change detection.

(BandA \& BandF) using RPC. About 12 GCPs was identified on both the images for Exterior orientation computation. Image matching has been performed between the fore and aft images. A total number of 100 match points called as Tie points were generated at higher correlation coefficients. Triangulation was performed using second order polynomial refinement.

\subsection{Three Dimensional (3-D) Feature Extraction}

Data extraction was performed using Pro600 and LPS. Stereoscopic vision was required to capture the features three dimensionally. Mass point layer or breakline creation is prerequisite for the feature extraction. The horizontal and vertical accuracy was maintained for every vertex throughout the stereo model. Three dimensional feature extractions was useful to represents the surface changes in the quarry. The surface may be generated with mass point or breakline.

\subsection{Volume Estimation}

Geographical Information System is an essential tool to calculate the volume of the quarry. Stereoscopically extracted features are in Microstation (.dgn) format and it is added as the layer into GIS software for the volume estimation. Arcscene is part of ArcGIS software is used for the volume estimation and visualisation. Volume estimation consists of 2 stages in the software namely surface generation using interpolation and surface area and volume estimation using the $3 \mathrm{~d}$ analyst. Quarry boundary delineation is shown in the Figure 3.

\section{Results and Discussion}

In this study, Lime stone quarry volume was predicted for the year 2006 and 2014. Figure 4 depicts the quarries of 2006 and 2014. Figure visualize the representation of eight quarries which were found in the study area for the period of 2006 and 2014. 

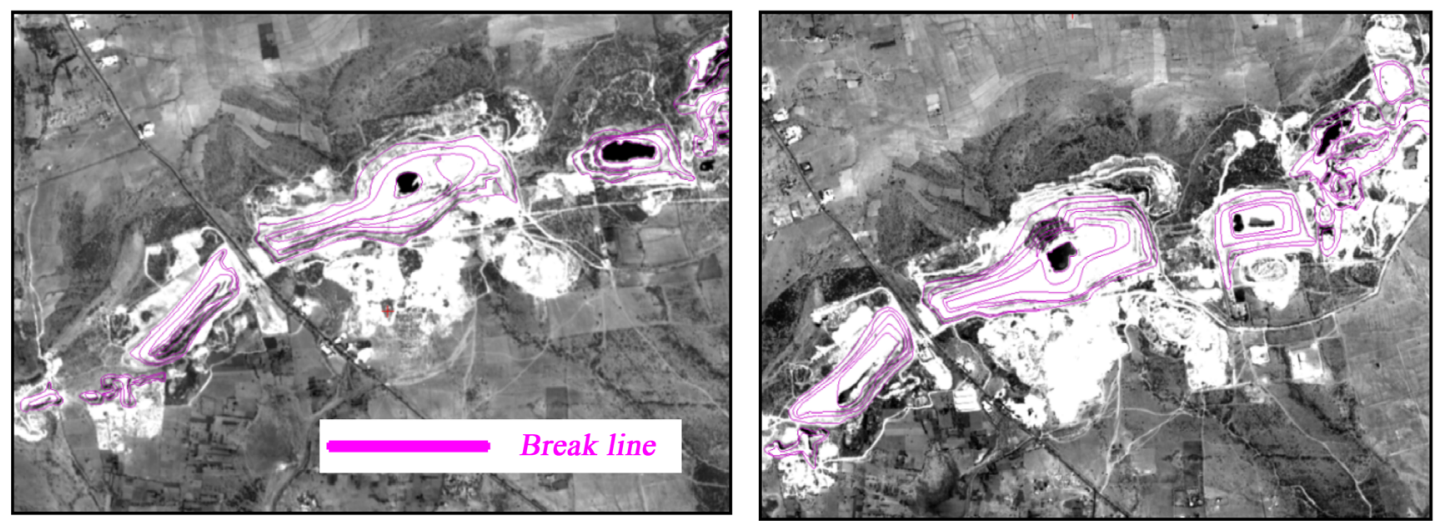

Figure 3. Volume derivation for the year 2006 (left) and 2014 (Right) using Leica Photogrammetry Suite.
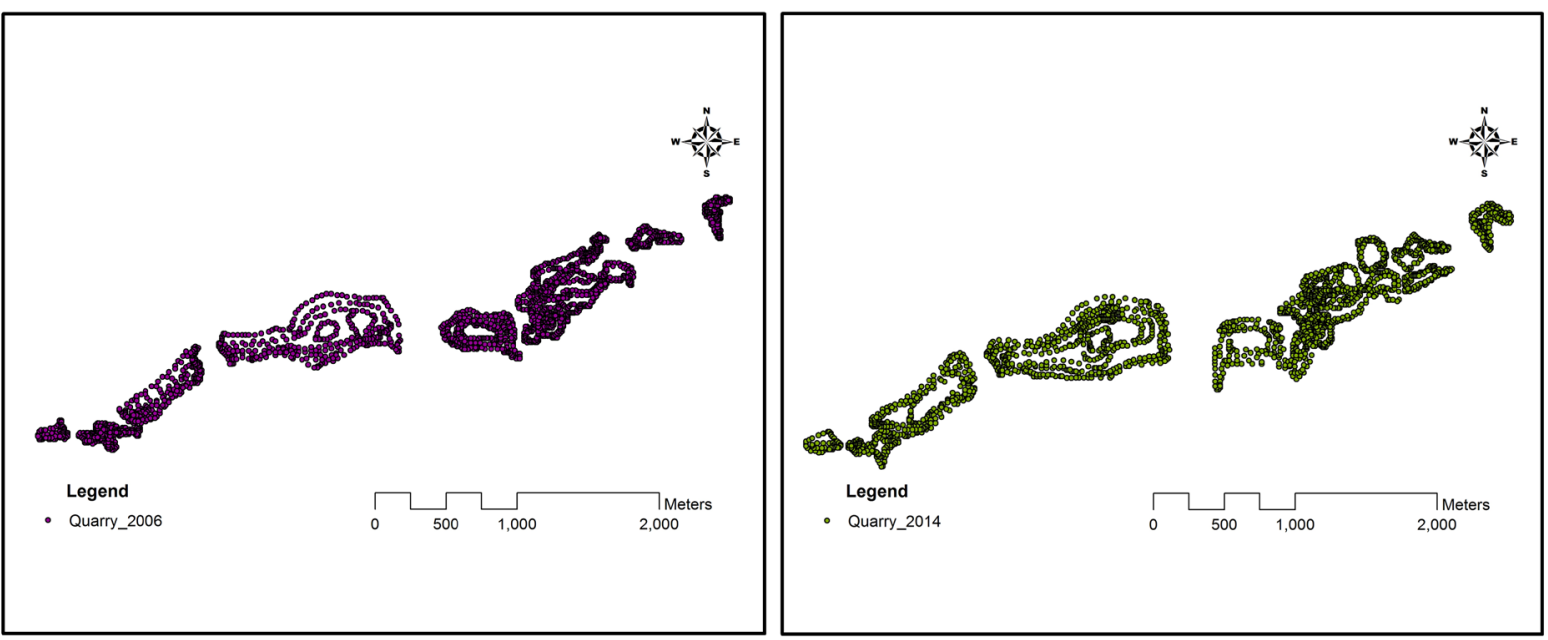

Figure 4. Quarry 2006 (left), 2014 (right).

\subsection{Quarry Site 1}

The surface area of site 1 in the quarry for the year 2006 is $28,039.36 \mathrm{~m}^{2}$ and volume for the site 1 is $497,273.79$ $\mathrm{m}^{3}$. It was tremendously increased to $35,038.26 \mathrm{~m}^{2}, 1,040,404.85 \mathrm{~m}^{3}$ in 2014 . There is about $20 \%$ increase in the surface area and $52 \%$ increase in the volume for the prolonged gap of eight years. It is depicted in the Figure 5.

\subsection{Quarry Site 2}

Figure 6 is a dynamic view of quarry site 2 used for the analysis of volume change in the year 2006 and 2014. From the statistical calibration, the surface area and volume for the year 2006 is found to be $80,577.17 \mathrm{~m}^{2}$, $2,139,890.74 \mathrm{~m}^{3}$ respectively and it is increased to $81,773.93 \mathrm{~m}^{2}, 2,428,145.501 \mathrm{~m}^{3}$ respectively. To be understandable, the increase in surface area is about $1.5 \%$ and the volume changes occurred is $12 \%$ for the last 8 years.

\subsection{Quarry Site 3}

The surface area and volume changes for the year 2006 and 2014 are shown in the Figure 7. The surface area and volume for the year 2006 is $310,652.78 \mathrm{~m}^{2}, 7,770,388.22 \mathrm{~m}^{3}$ respectively is being increased to $418,708.7 \mathrm{~m}^{2}$, $9,357,416.25 \mathrm{~m}^{3}$. It is $25 \%$ and $17 \%$ increases in the surface area and volume changes for the last eight years.

\subsection{Quarry Site 4}

The rise of surface area is $25 \%$ and the volumes that are excavated are $17 \%$ for the year 2006 and 2014 that 

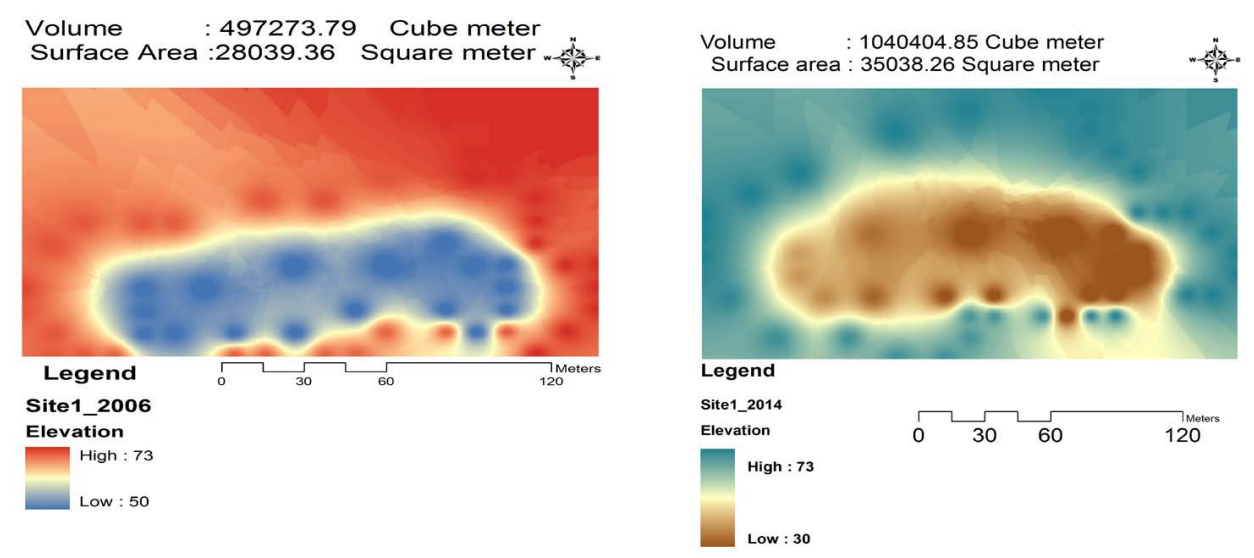

Figure 5. Surface area and volume at Site-1 2006 (left) and 2014 (right).
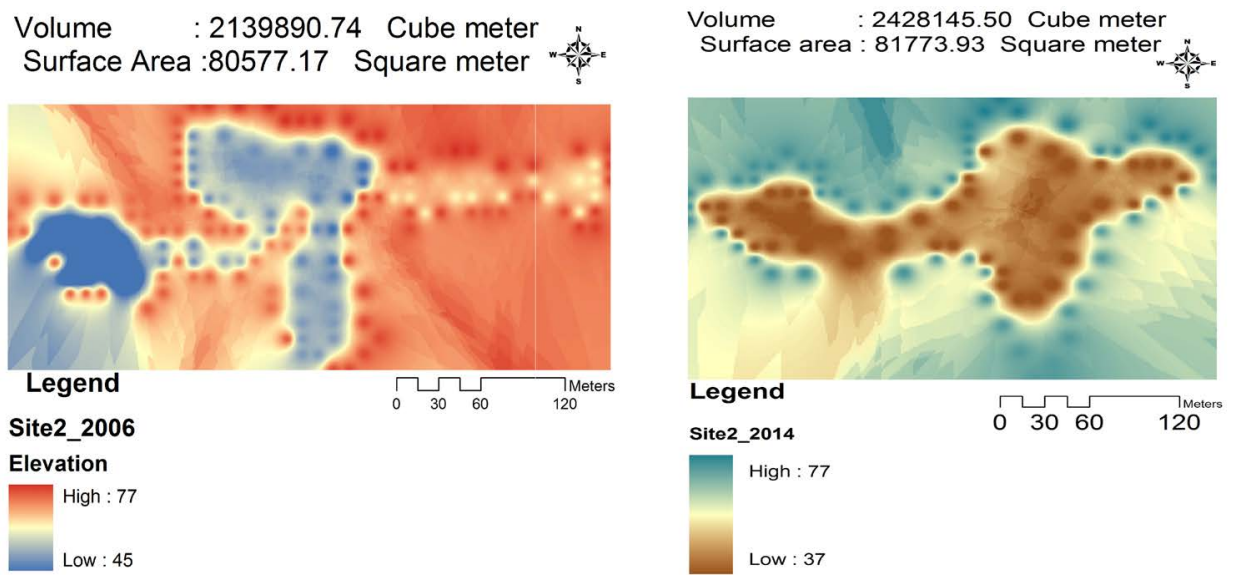

Figure 6. Surface area and volume at Site-2 2006 (left) and 2014 (right).

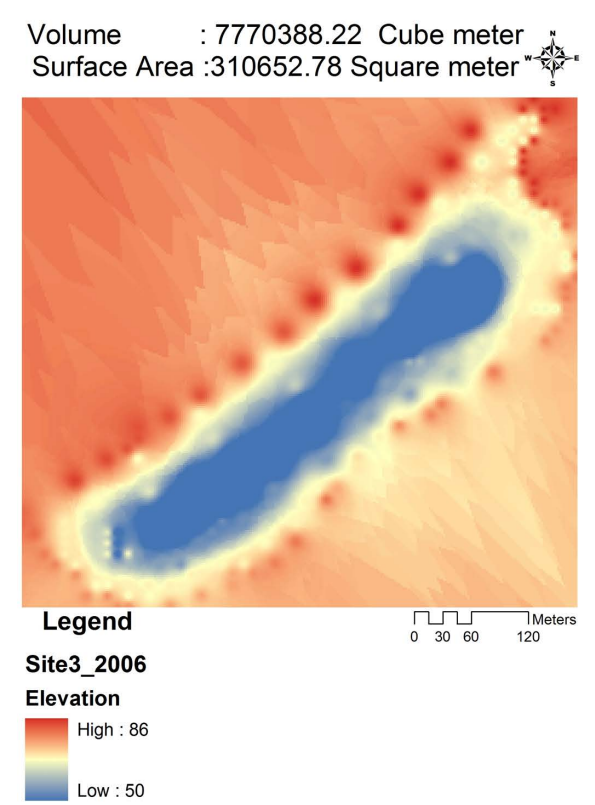


were indicated in Figure 8. The surface area and volume for the year 2006 is 660,113.52 $\mathrm{m}^{2}$, 46,913,883.35 $\mathrm{m}^{3}$ which was raised to $729,853.93 \mathrm{~m}^{2}, 51,870,293.66 \mathrm{~m}^{3}$ respectively for the last 8 years.

\subsection{Quarry Site 5}

The surface area and volume changes for the year 2006 and 2014 are represented in the Figure 9. The surface area and volume for the year 2006 is $188,151.34 \mathrm{~m}^{2}, 3,534,875.44 \mathrm{~m}^{3}$ respectively is increased to $236,596.48 \mathrm{~m}^{2}$, $5,068,490.58 \mathrm{~m}^{3}$. It is $20 \%$ and $30 \%$ increase in the surface area and volume changes in 2014 .

\subsection{Quarry Site 6}

The surface area and volume of excavation for the year 2006 is $615,313.04 \mathrm{~m}^{2}, 50,371,989.56 \mathrm{~m}^{3}$ and are shockingly increased to $1,197,066.17 \mathrm{~m}^{2}, 84,646,150.29 \mathrm{~m}^{3}$. The $48 \%$ increase in surface area and $40 \%$ increase in volume have been determined at the end of the study. The surface area and volume changes for the year 2006 and 2014 are proven through the Figure 10.

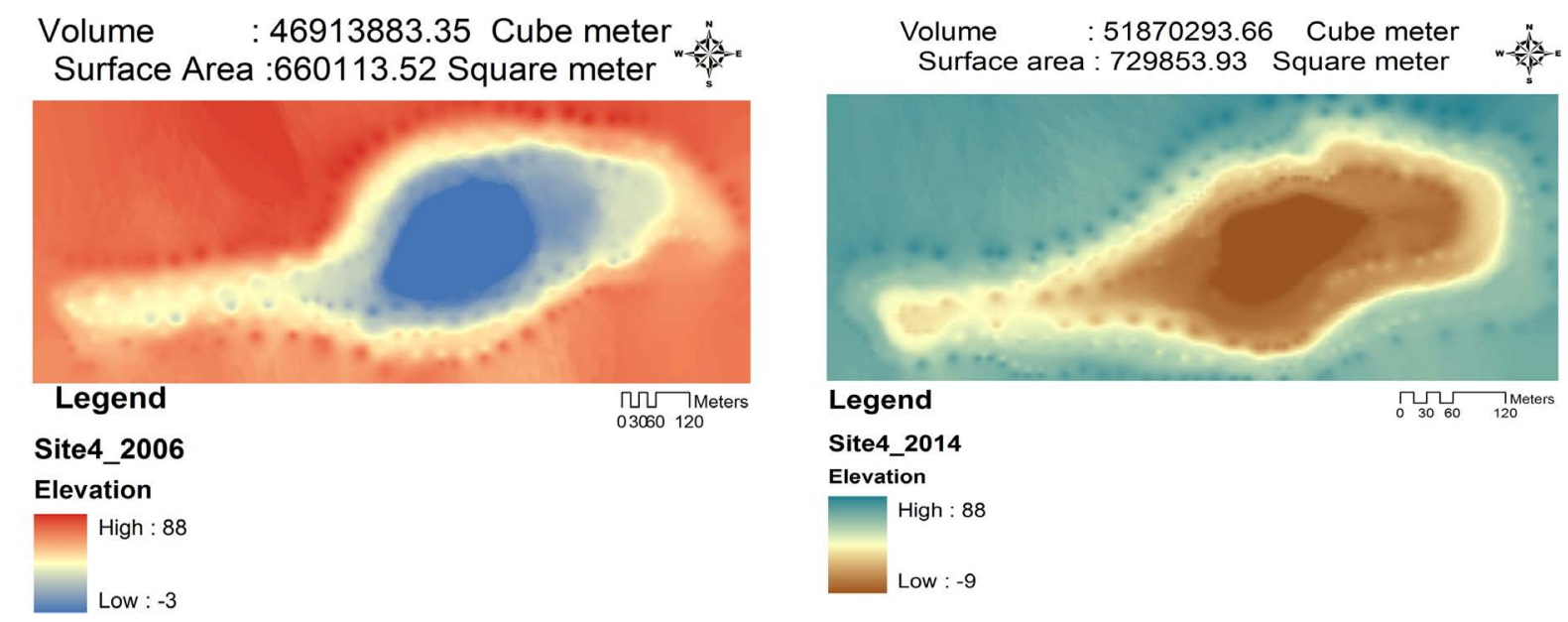

Figure 8. Surface area and Volume at Site-4 2006 (left) and 2014 (right).

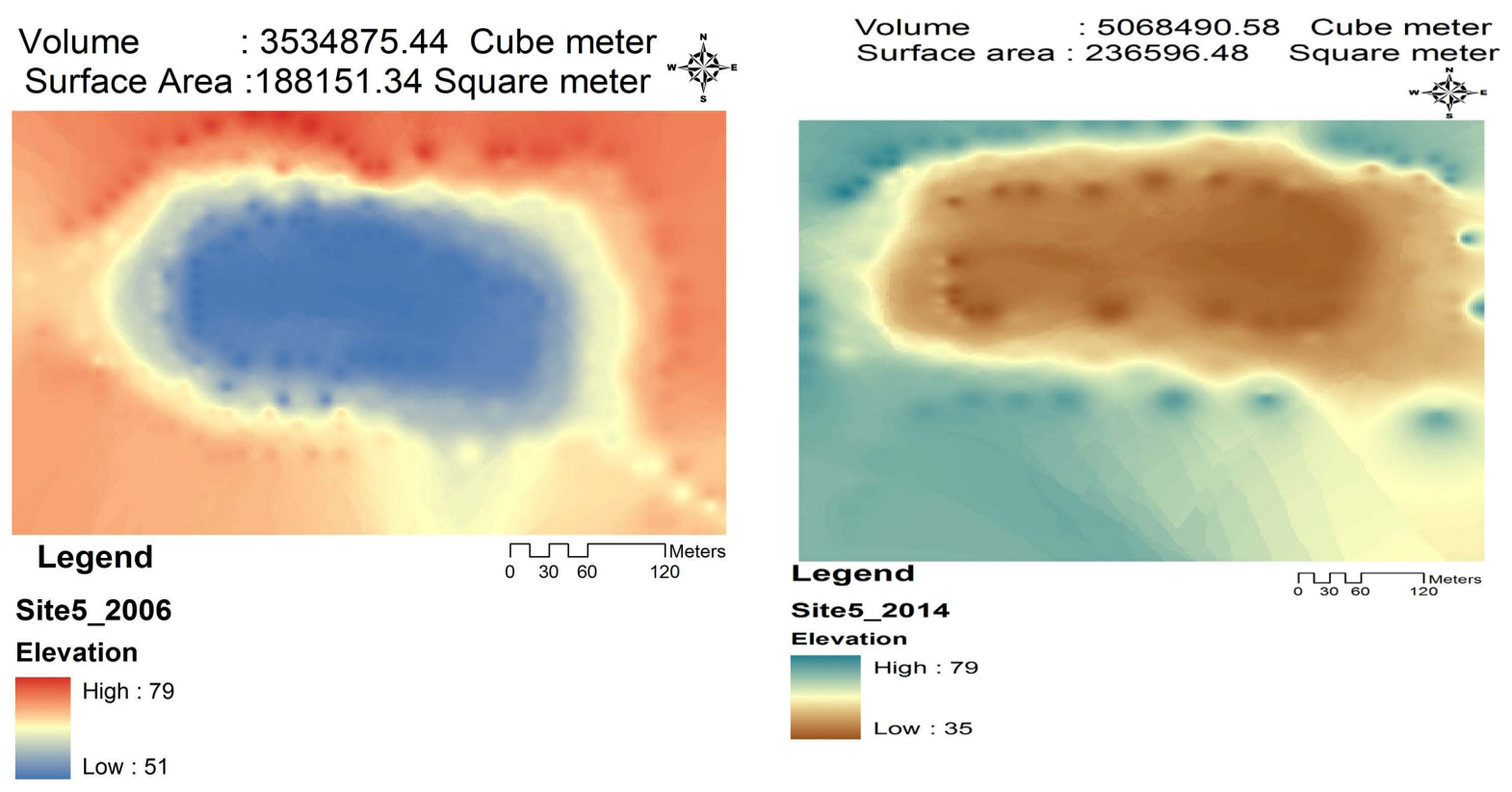

Figure 9. Surface area and Volume at Site-5 2006 (left) and 2014 (right). 


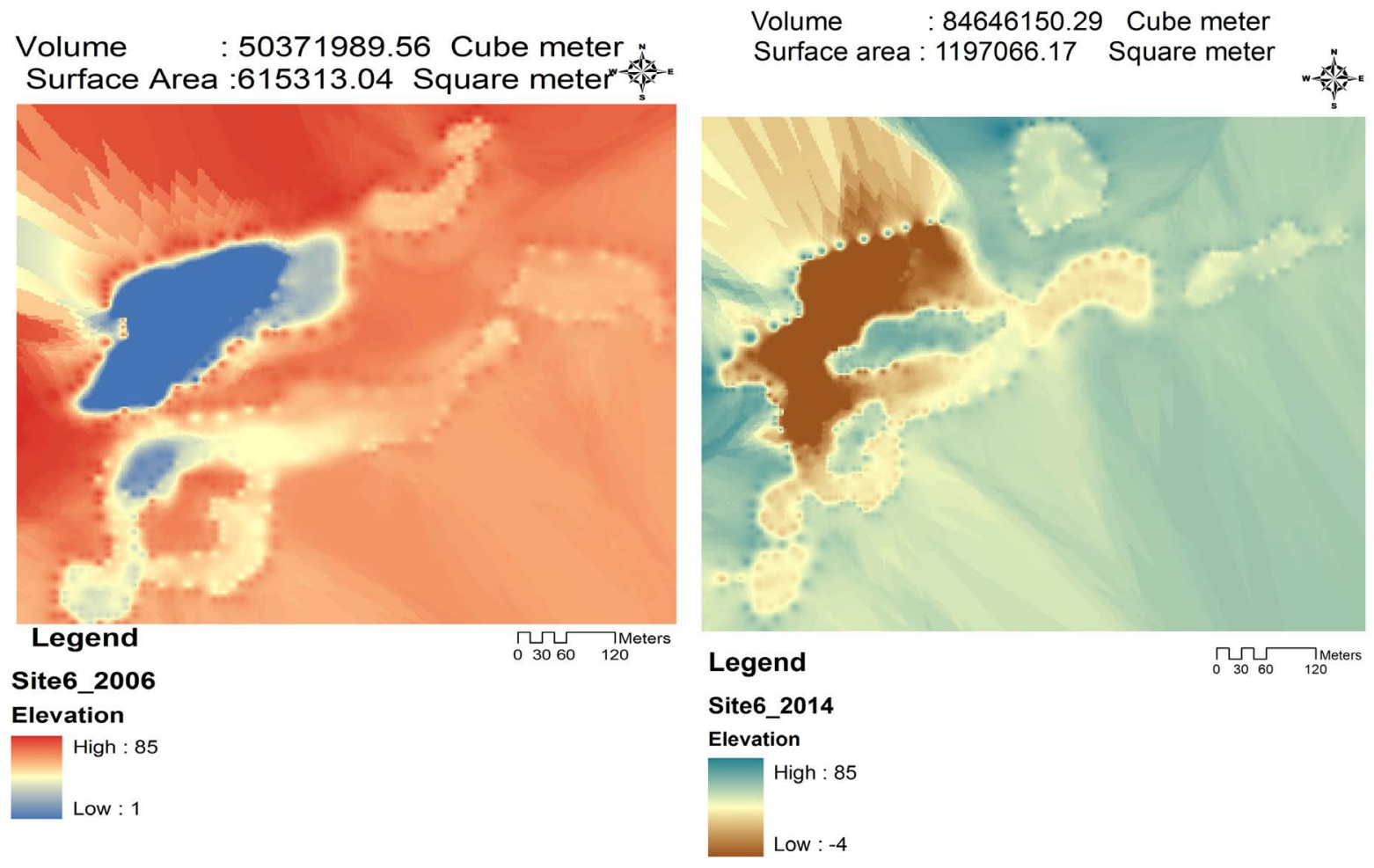

Figure 10. Surface area and Volume at Site-6 2006 (left) and 2014 (right).

\subsection{Quarry Site 7}

The site 7 as same as other there have been found some changes in surface area and volume of lime stone excavated throughout the year of 2006 and 2014 are viewed in the Figure 11. The surface area and volume for the year 2006 is $58,245.36 \mathrm{~m}^{2}, 517,748.09 \mathrm{~m}^{3}$ and is increased to $93,971.82 \mathrm{~m}^{2}, 906,475.94 \mathrm{~m}^{3}$ for the period of 2014. It is $38 \%$ and $42 \%$ increase in the surface area and volume of excavation in quarry for the late 8 years.

\subsection{Quarry Site 8}

The site 8 is symbolizing a lot of excavation is depicted in the Figure 12. The surface area and volume of excavation for the year 2006 is $50,667.11 \mathrm{~m}^{2}, 652,882.74 \mathrm{~m}^{3}$ and reached to the value of $88,375.35 \mathrm{~m}^{2}$, and $1,489,552.84 \mathrm{~m}^{3}$ in the year 2014 . It is $42 \%$ and $56 \%$ increase in the surface area and volume changes for the last 8 years.

\section{Conclusion}

Though the number of quarry remains the same from 2006 to 2014, utilization of the quarry surface area and volume of limestone production has increased drastically which is a catastrophe to the environment. The surface area and volume of the lime stone quarry was excavated in the year 2006 was 1,991,759.68 $\mathrm{m}^{2}$ and 112,398,931.9 $\mathrm{m}^{3}$. It was increased to $2,881,384.64 \mathrm{~m}^{2}, 156,806,929.9 \mathrm{~m}^{3}$ in the year 2014 . Nearly $30 \%$ raise of surface area and $28 \%$ boost of volume changes were occurred. The study made clear that all eight quarry sites had it increased surface area and volume by the year 2014. In 2006 quarry site 1 proven by its surface area was $28,039.36 \mathrm{~m}^{2}$ and volume was $497,273.79 \mathrm{~m}^{3}$ have increased largely to $35,038.26 \mathrm{~m}^{2}, 1,040,404.85 \mathrm{~m}^{3}$ in 2014 . It was $20 \%$ and $52 \%$ increase in the surface area and volume of excavation. In the same way, the changes of surface area and excavated volume for the other sites were $1.45 \%, 11.87 \%$ site $2,25.8 \%, 16.96 \%$ in the site $3,9 \%, 9.5 \%$ (site 4 ), 20.47\%, 30.25\% (site 5), 48.59\%, 40.49\% (site 6), 48.59\%, 40.49\% (site 7) and 42.6\%, 56.16\% (site 8). It was clear from the result that highest surface area changes were found in quarry site 6 and the highest volume changes occurred in the site 8. This study concluded that Cartosat-1 generated DEM was easy and effective in natural resources change detection among different epochs. 


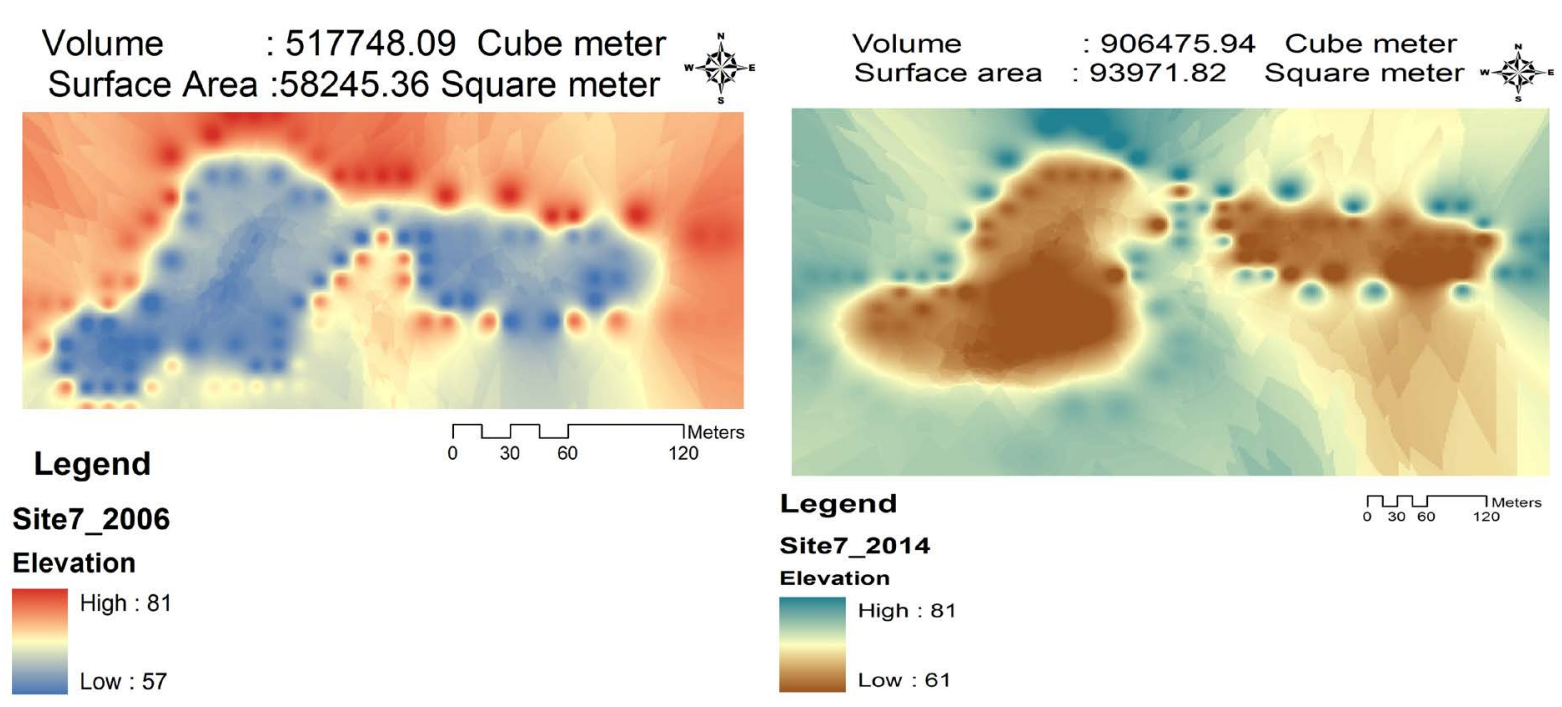

Figure 11. Surface area and Volume at Site-7 2006 (left) and 2014 (right).

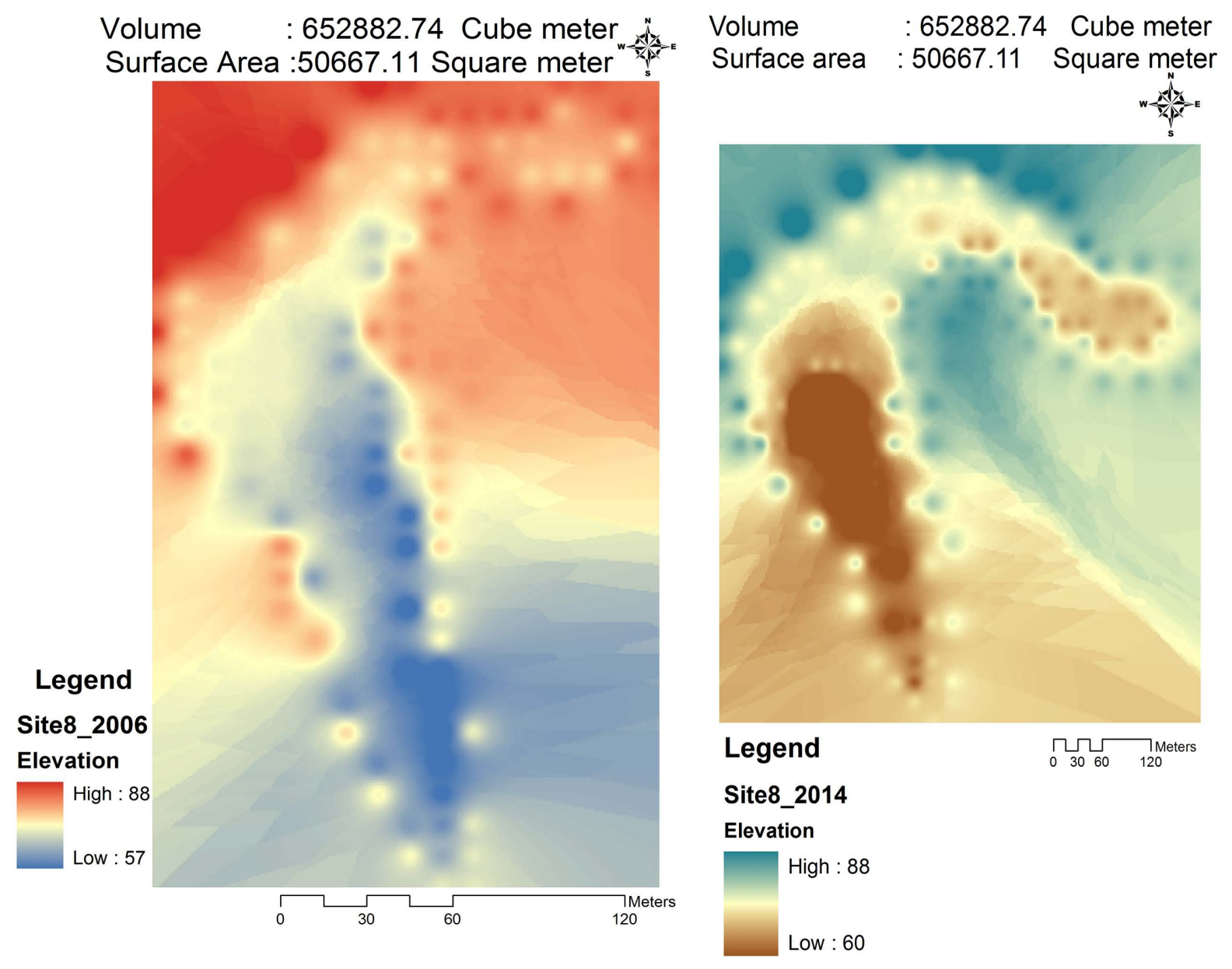

Figure 12. Surface area and Volume at Site-8 2006 (left) and 2014 (right).

\section{Acknowledgements}

We thank Regional campus Anna university, Tirunelveli Dean for providing the data for this research. 


\section{References}

[1] Mondal, S., Chakravarty, D. and Bandayopadhyay, J. (2013) Application of GIS Techniques for Assessment of Changes in Land Use Pattern and Environmental Impact of Mines over a Small Part of Keonjhar District of Orissa. IOSR Journal of Research \& Method in Education (IOSR-JRME), 2, 49-62.

[2] Mondal, S., Bandayopadhyay, J. and Chakravatry, D. (2014) Scientific Investigation of the Environmental Impact of Mines Using Geospatial Techniques over a Small Part of Keonjhar District of Orissa. International Journal of Scientific and Research Publications, 4, 1-8.

[3] Latifovica, R., Fytasb, K., Chenc, J. and Paraszczakb, J. (2005) Assessing Land Cover Change Resulting from Large Surface Mining Development. International Journal of Applied Earth Observation and Geoinformation, 7, 29-48. http://dx.doi.org/10.1016/j.jag.2004.11.003

[4] Nanor, V.K.N.J.N. and Klaku, R.K. (2012) Effects of Quarry Activities on Some Selected Communities in the Lower Manya Krobo District of the Eastern Region of Ghana. Atmospheric and Climate Sciences, 2, 362-372.

[5] Vorovencii, I. (2011) Satellite Remote Sensing in Environmental Impact Assessment: An Overview. Bulletin of the Transilvania University of Braşov, 4, 73-80.

[6] Suraj, R. (2014) Clay Mining and Land Use/Land Cover change of Thrissur district, Kerala, India Using Geospatial Techniques. ISRS Proceeding Papers of Sort Interactive Session ISPRS TC VIII International Symposium on Operational Remote Sensing Applications: Opportunities, Progress and Challenges, Hyderabad, 9-12 December 2014.

[7] Woldai, T. (2001) Application of Remotely Sensed Data and GIS in Assessing the Impact of Mining Activities on the Environment. 17th International Mining Congress and Exhibition of Turkey-IMCET, 75-83.

[8] Bhatnagar, D., Goyal, S., Dignath, S. and Deolia, D.K. (2014) Impact of Opencast Limestone Mining on Groundwater in Katni River Watershed, Madhya Pradesh, India-A Geoinformatics Approach. Journal of Geomatics, 8, 101-106.

[9] El Tahlawi, M.R. and Ahmed, S.S. (2006) Environmental Impact of Mining Operations with Case Study of Abu Tartour Mine, Egypt. The 3rd International Conference for Develop and the Environment in the Arab world, Egypt, 21-23 March 2006, 339-355.

[10] Saroglu, E., Bektas, F., Dogru, A.O., Ormeci, C.N. and Musaoglu, K.S. (2005) Environmental Impact Analysis of Quarries Located on the Asian Side of Istanbul Using Remote Sensing Data. XXII International Cartographic Conference (ICC2005), A Coruña, 11-16 July 2005

[11] Anderson, A.T., Schultz, D., Buchman, N. and Nock, H.M. (1977) LandSAT Imagery for Surface Mining Inventory. Photogrammetric Engineering and Remote Sensing, 43, 1027-1036.

[12] González-Aguilera, D., Fernández-Hernández, J., Mancera-Taboada, J., Rodríguez-Gonzálvez, P., Hernández-López, D., Felipe-García, B., Gozalo-Sanz, I. and Arias-Perez, B. (2012) 3D Modelling and Accuracy Assessment of Granite Quarry Using Unmmanned Aerial Vehicle. ISPRS Annals of the Photogrammetry, Remote Sensing and Spatial Information Sciences, XXII ISPRS Congress, Melbourne, 25 August-1 September 2012.

[13] Nikolaos, G., Konstantinos, A., Nikolakopoulos, G. and Dimitropoulou, K. (2014) Open-Pit Mine Monitoring Using Remote Sensing and GIS. 5th EARSeL Workshop on Remote Sensing and Geology Surveying the GEOsphere Warsaw, Poland, 19-20 June 2014.

[14] Krishna Murthy, Y.V.N., Srinivasa Rao, S., Prakasa Rao, D.S. and Jayaraman, V. (2008) Analysis of DEM Generated Using CartoSAT-1 Stereo Data over Mausanne Les Alpiles-CartoSAT Scientific Appraisal Programme. The International Archives of the Photogrammetry, Remote Sensing and Spatial Information Sciences, Vol. 37, Part B1, Beijing.

[15] Equbal, Md.Z. and Ambica, A. (2012) Environmental Impact Assessment of Salem Chalk Hills Using Remote Sensing and GIS. International Journal of Computer Trends and Technology, 3, 1-11. 